\title{
The effects of dietary ricinoleic acid from castor oil on the zootechnical traits and haemato-biochemical profile of lactating Kankrej cows
}

\author{
Mahesh M. Pawar ${ }^{1 *}$, Pratikkumar C. Joshi ${ }^{1}$, Yogesh M. Gami², Shrikant S. Patil ${ }^{1}$, \\ Mayank P. Patel ${ }^{2}$, and Jasmi G. Patel ${ }^{3}$ \\ ${ }^{1}$ Department of Animal Nutrition, College of Veterinary Science and Animal Husbandry, Sardarkrushinagar \\ Dantiwada Agricultural University, Sardarkrushinagar, Gujarat, India \\ ${ }^{2}$ Livestock Research Station, Sardarkrushinagar Dantiwada Agricultural University, Sardarkrushinagar, \\ Gujarat, India \\ ${ }^{3}$ Department of Veterinary Pathology, College of Veterinary Science and Animal Husbandry, Sardarkrushinagar \\ Dantiwada Agricultural University, Sardarkrushinagar, Gujarat, India
}

PAWAR, M. M., P. C. JOSHI, Y. M. GAMI, S. S. PATIL, M. P. PATEL, J. G. PATEL: The effects of dietary ricinoleic acid from castor oil on the zootechnical traits and haemato-biochemical profile of lactating Kankrej cows. Vet. arhiv 91, 125-135, 2021.

\section{ABSTRACT}

The aim of the present study was to evaluate the effects of dietary ricinoleic acid from castor oil on the milk yield, composition, fatty acid profile and haemato-biochemical profile in lactating Kankrej cows. Twenty lactating Kankrej cows were assigned to the following groups: control (CON), basal diet without any additive and treatment (RAS), basal diet with $2 \mathrm{~g} / \mathrm{animal} / \mathrm{day}$ of ricinoleic acid from castor oil. Dietary ricinoleic acid had no $(\mathrm{P}>0.05)$ effect on dry matter intake and feed efficiency. Milk yield (milk, $4 \%$ fat corrected milk and energy corrected milk) were not affected $(\mathrm{P}>0.05)$ by the feeding of ricinoleic acid. The milk composition showed no significant differences between the groups. A significantly $(\mathrm{P}<0.05)$ higher percentage of $\mathrm{C} 4: 0, \mathrm{C} 6: 0$ and $\mathrm{C} 8: 0$ was found in the milk from the RAS group than the $\mathrm{CON}$ group. A lower $(\mathrm{P}<0.05)$ milk $\mathrm{C} 16: 0$ percentage was observed in the RAS group as compared to the CON. The percentages of C18:2 and C18:3 were found to be increased in the RAS group. There was a decrease $(\mathrm{P}=0.055)$ in milk saturated fatty acids but an increase in milk unsaturated fatty acids percentage in the RAS as compared to the CON group. The milk polyunsaturated fatty acids were significantly $(\mathrm{P}<0.05)$ increased in the RAS group. There was no difference $(\mathrm{P}>0.05)$ in haemato-biochemical profile between the CON and RAS groups. It was concluded that supplementation of $2 \mathrm{~g} /$ animal/day ricinoleic acid from castor oil had no effect on milk yield, milk composition and haemato-biochemical profile. However, it increased the milk fat percentages of unsaturated fatty acids and polyunsaturated fatty acids, and decreased milk saturated fatty acids, without any adverse effect on the health status of the cows.

Key words: Kankrej cow; milk yield; fatty acid profile; blood metabolites; ricinoleic acid

\footnotetext{
*Corresponding author:

Dr. M. M. Pawar, M.V.Sc., Ph.D., Department of Animal Nutrition, College of Veterinary Science and Animal Husbandry, Sardarkrushinagar Dantiwada Agricultural University, Sardarkrushinagar - 385506, Gujarat, India, Phone: +91 96 3896 3132; E-mail: mahespawar@gmail.com
} 


\section{Introduction}

Ruminal biohydrogenation of the dietary unsaturated fatty acids (UFA) ingested by ruminants results in the production of saturated fatty acids (SFA) at the expense of the UFA. Milk and dairy products are a major source of SFA in the human diet, but also serve as a versatile source of nutrients (KLIEM and SHINGFIELD, 2016). Public health policies recommend a population wide decrease in the consumption of SFA to lower the incidence of cardiovascular and metabolic diseases. Altering milk fat composition offers the opportunity to replace the SFA in milk fat with monounsaturated fatty acids (MUFA) and polyunsaturated fatty acids (PUFA). Animal scientists are experimenting with various alternative strategies to manipulate the ruminal biohydrogenation process, in order to obtain meats and milk with a lower SFA content, which would be of great value for consumer health. To avoid the use of synthetic molecules or antibiotics in livestock farming, animal scientists are focusing on the use of plant bioactive lipid compounds as potential modulators of ruminal fermentation and enhancers of animal productivity (HAUSMANN et al., 2018; PAWAR et al., 2019). Plant bioactive lipid molecules, such as ricinoleic acid from castor oil may have several beneficial responses in animal production. Ricinoleic acid (12-hydroxycis-9-18:1) is the main fatty acid component (about $90 \%$ ) of castor oil, which is obtained by pressing castor seeds (TORRENTES-ESPINOZA et al., 2017). Ricinoleic acid acts as a functional oil by providing health benefits, viz. antimicrobial (FERREIRA et al. 2002), anti-inflammatory (VIEIRA et al. 2000), anti-oxidative (TREVISAN et al. 2006), and gastro-protective (HAMAD and MUBOFU, 2015) properties, besides its nutritive properties. The addition of ricinoleic acid/castor oil improved rumen fermentation, increasing the molar proportion of propionate and decreasing ammonia nitrogen concentration, and a relative abundance of methanogenic archaea has been reported in in vitro and in vivo research (SERADJ et al., 2017; KANG et al., 2018; KONDA et al., 2019). Propionate is the mostimportant substrate for hepatic gluconeogenesis (accounting for $60-74 \%$ of the total substrate) and is highly associated with milk production in dairy cows (ASCHENBACH et al., 2010; HAMMON et al., 2010). Recent studies have shown that castor oil/functional oil supplementation increased the milk yield of dairy cows (GANDRA et al., 2014; FERREIRA DE JESUS et al., 2016; MATLOUP et al., 2017; JOSHI, 2019). In vitro studies showed that ricinoleic acid modulates the biohydrogenation of UFA, and increases the content in vaccenic and rumenic acids, leading to the increased concentrations of trans-18:1 and CLA isomers (MORALES et al., 2012; ALVES et al., 2017). To test these hypotheses, we assessed the effects of the dietary addition of ricinoleic acid from castor oil on milk yield, composition, fatty acid profile and blood parameters in lactating Kankrej cows.

\section{Materials and methods}

The use of the animals and the experimental procedure were approved by the Institutional Animal Ethics Committee (IAEC) constituted as per the Article 13 of the rules of the Committee for the Purpose of Control and Supervision on Experiments on Animals (CPCSEA), laid down by the Government of India. The IAEC approval number is VETCOLL/IAEC/2018/13/ PROTOCOL-2.

Animals, feeding and experimental design. Twenty primiparous Kankrej cows (average 21 days in milk; $8.84 \mathrm{~kg} / \mathrm{d}$ of milk yield and 340 $\mathrm{kg}$ of body weight) were selected from the herd maintained at the Livestock Research Station, Sardarkrushinagar Dantiwada Agricultural University, Sardarkrushinagar, Gujarat, India. It is located in semi-arid region at a latitude of $24.35^{\circ}$ North and longitude of $72.59^{\circ}$ East, and an elevation of 189 meters above mean sea level. The cows were randomly assigned to the following treatments: control $(\mathrm{CON})$, basal diet (consisting of concentrate mixture, green lucerne fodder and jowar hay) without feed additive; 2), Ricinoleic acid (RAS), basal diet with $2 \mathrm{~g} / \mathrm{d} / \mathrm{cow}$ of ricinoleic acid added. Ricinoleic acid was mixed thoroughly into concentrate and provided once daily for period of 56 days. The basal diet was formulated to meet 
M. M. Pawar et al.: Production performance of dairy cows fed with ricinoleic acid

Table 1. Chemical composition (\% DM basis) of concentrate, Lucerne and jowar hay in the diet of lactating Kankrej cows

\begin{tabular}{|l|c|c|c|}
\hline Composition & Concentrate mixture & Jowar hay & Green Lucerne \\
\hline Dry matter & 95.55 & 89.73 & 19.92 \\
\hline Crude protein & 18.59 & 2.29 & 18.76 \\
\hline Crude fibre & 6.58 & 37.58 & 22.64 \\
\hline Ether extract & 2.43 & 1.36 & 2.93 \\
\hline Ash & 8.25 & 10.51 & 9.38 \\
\hline NFC & 35.53 & 28.22 & 27.80 \\
\hline NDF & 35.2 & 57.62 & 41.13 \\
\hline ADF & 19.05 & 45.17 & 21.15 \\
\hline
\end{tabular}

NFC - Non-fibre carbohydrate, calculated by equation: NFC $(\%$ of DM $)=100-(C P+N D F+E E+$ ash $)$; NDF - Neutral detergent fibre; ADF - Acid detergent fibre.

ICAR (2013) nutrient requirements. The chemical composition of feeds and fodders fed to the experimental animals is given in Table 1.

Sampling and chemical analysis. The feeds offered and subsequent left-overs were recorded for each animal in order to calculate feed intake. Samples of feeds and fodders were collected, composited and dried at $60{ }^{\circ} \mathrm{C}$ in a forced air oven for $48 \mathrm{~h}$, and ground to pass through a 1-mm screen using a Wiley mill (Star Scientific Instruments, Delhi, India). The feeds samples were analysed for dry matter (DM, method 934.01), ash (method 942.05), crude protein (method 976.05) and ether extract (method 973.18) according to AOAC (2007). Neutral detergent fibre and acid detergent fibre were determined as per VAN SOEST et al. (1991). Nonfibre carbohydrate was calculated according to NRC (2001). The cows were milked twice a day, and the individual milk yield for each cow was recorded daily using an electronic weighing balance. The $4 \%$ fat corrected milk (FCM) was calculated as stated by GAINS (1928): milk yield (kg) x 0.4 + fat yield $(\mathrm{kg})$ x 15 . Energy corrected milk (ECM) was determined according to DAVIDSON et al. (2008): $0.327 \times$ milk yield $(\mathrm{kg} /$ day $)+12.86 \times$ fat yield $(\mathrm{kg} /$ day) $+7.65 \times$ protein yield $(\mathrm{kg} /$ day $)$. Milk samples were collected at fortnightly intervals for analysis of milk composition (fat, solids-not fat (SNF), protein and lactose) using an EKOMILK Ultra Pro Milk Analyser (Everest Instruments Pvt. Ltd.).

Determination of milk fatty acid profile. Milk fatty acids were analysed by isolating milk fat by centrifugation and methylation using sodium methylate, according to O'FALLON et al. (2007). Fatty acid methyl esters were analysed using a gas chromatograph (Thermo Scientific Ceres 800) with flame ionization detector and capillary column $(60 \mathrm{~m} \times 0.25 \mathrm{~mm} \times 0.20 \mathrm{~mm})$. The initial oven temperature was $120{ }^{\circ} \mathrm{C}$, held for $5 \mathrm{~min}$, subsequently increased to $240{ }^{\circ} \mathrm{C}$ at a rate of $2{ }^{\circ} \mathrm{C}$ $\mathrm{min}^{-1}$, and then held for $60 \mathrm{~min}$. Nitrogen at a flow rate of $1 \mathrm{ml} / \mathrm{min}$ was used as the carrier gas. Both the injector and the detector were set at $260{ }^{\circ} \mathrm{C}$. As an internal standard fatty acid Heptadecanoic acid C17:0 (Catalogue number H3500, SigmaAldrich, Bangalore, India) was used, and a mix of FAME standards (Supelco 37 Component FAME Mix, Sigma Aldrich, Bangalore, India) was used to generate a calibration curve. Fatty acids were identified by comparing their retention times with the fatty acid methyl standards, and were expressed as a percentage of the total fatty acids.

Blood sampling and analysis. On the $56^{\text {th }}$ day of experimental feeding, blood samples were collected from the jugular vein of each animal into vials (BD Vacutainer $^{\circledR}$ Spray-coated K2EDTA Tubes, BD Franklin Lakes, NJ, USA) with and without EDTA 
(BD Vacutainer ${ }^{\circledR}$ Plus Plastic Serum Tubes, BD Franklin Lakes, NJ, USA). The fresh blood samples were analysed for haemoglobin, haematocrit, erythrocytes, mean corpuscular volume (MCV), mean corpuscular haemoglobin $(\mathrm{MCH})$, mean corpuscular haemoglobin concentration (MCHC), absolute numbers of leucocytes, neutrophils, lymphocytes and monocytes using Exigo EOS Vet Haematology Analyser (Boule Medical AB, Sweden).

The serum samples were analysed for concentrations of glucose, total proteins, albumin, urea, creatinine, triglycerides, cholesterol, calcium and inorganic phosphorus along with activity

\section{Results}

Dietary ricinoleic acid had no $(\mathrm{P}>0.05)$ effect on DM intake in lactating Kankrej cows (Table 2). The DM intake was $8.81 \pm 0.27$ and $9.15 \pm 0.23 \mathrm{~kg} / \mathrm{d}$ in the CON and RAS groups, respectively. Milk yields in terms of $\mathrm{kg} / \mathrm{d}, 4 \% \mathrm{FCM}$ and ECM were not affected $(\mathrm{P}>0.05)$ by feeding with ricinoleic acid as compared to the CON. No differences $(\mathrm{P}>0.05)$ were observed in yields of milk fat, SNF, total solids, protein and lactose between the CON and RAS groups. The milk compositions (fat, SNF, total solids, protein and lactose) were comparable without any difference $(\mathrm{P}>0.05)$ between the groups. Feed efficiency [milk (kg)/DMI ( $\mathrm{kg}), 4 \%$ FCM (kg)/DMI ( $\mathrm{kg})$ and ECM (kg)/DMI (kg)] did not differ $(\mathrm{P}>0.05)$ between the CON and RAS groups.

Following the dietary addition of ricinoleic acid modified milk fatty acids profile (Table 3 ) the milk from the RAS group had significantly $(\mathrm{P}<0.05)$ higher percentages of short chain fatty acids such as $\mathrm{C} 4: 0, \mathrm{C} 6: 0$ and $\mathrm{C} 8: 0$ than the $\mathrm{CON}$ group. $\mathrm{A}$ significantly $(\mathrm{P}<0.05)$ lower percentage of $\mathrm{C} 16: 0$ long chain fatty acid was observed in the RAS as compared to the CON group. The percentages of C18:2 and C18:3 were found to be significantly $(\mathrm{P}<0.05)$ higher in the RAS group than in the CON of alanine aminotransferase (ALT), aspartate aminotransferase (AST), alkaline phosphatase (ALP) and gamma-glutamyl transferase (GGT), using a Randox Monaco Analyser (Randox Laboratories Ltd., UK).

Statistical analysis. All the experimental data obtained were statistically analysed using SPSS v.16.0 (SPSS Inc., Chicago IL) as per the standard statistical methods (SNEDECOR and COCHRAN, 1994). Significant differences between means of treatments were assessed by Duncan's test, and the differences between treatments were declared significant at $\mathrm{P}<0.05$.

group. Feeding of ricinoleic acid resulted in a decrease $(\mathrm{P}=0.055)$ in the percentages of milk SFA (70.82 \pm 1.40 vs. $74.27 \pm 0.92)$ and an increase $(\mathrm{P}=$ $0.055)$ in milk UFA $(5.73 \pm 0.92$ vs. $29.18 \pm 1.40)$ in the RAS as compared to the CON group. The PUFA were $2.58 \pm 0.10$ and $4.65 \pm 0.48 \mathrm{~g} / 100 \mathrm{~g}$ in the CON and RAS groups, respectively, and were significantly $(\mathrm{P}<0.05)$ higher in the RAS group than in the CON.

There was no effect $(\mathrm{P}>0.05)$ on the mean concentrations of red blood cells (haemoglobin, haematocrits, erythrocytes, $\mathrm{MCV}, \mathrm{MCH}, \mathrm{MCHC})$ and white blood cells (leucocytes, neutrophils, lymphocytes, monocytes) in the CON and RAS groups (Table 4$)$. No difference $(\mathrm{P}>0.05$ ) was found in serum concentrations of total proteins, albumin, globulin, creatinine, triglycerides, cholesterol, ALT, AST, ALP, GGT, calcium and inorganic phosphorus between the two groups (Table 5). 
M. M. Pawar et al.: Production performance of dairy cows fed with ricinoleic acid

Table 2. The effect of supplementation of ricinoleic acid on dry matter intake, milk yield and milk composition in lactating Kankrej cows $(n=20)$

\begin{tabular}{|c|c|c|c|}
\hline Parameters & $\mathrm{CON}$ & RAS & P value \\
\hline \multicolumn{4}{|l|}{ Dry matter intake (DMI) } \\
\hline DMI (kg/d) & $8.81 \pm 0.27$ & $9.15 \pm 0.23$ & 0.341 \\
\hline \multicolumn{4}{|l|}{ Yield (kg/d) } \\
\hline Milk & $9.92 \pm 0.47$ & $9.42 \pm 0.54$ & 0.489 \\
\hline $4 \% \mathrm{FCM}$ & $10.30 \pm 0.61$ & $9.67 \pm 0.55$ & 0.448 \\
\hline ECM & $11.15 \pm 0.59$ & $10.58 \pm 0.59$ & 0.505 \\
\hline Fat & $0.42 \pm 0.03$ & $0.39 \pm 0.02$ & 0.453 \\
\hline Solids not fat & $0.81 \pm 0.04$ & $0.77 \pm 0.05$ & 0.459 \\
\hline Total solids & $1.23 \pm 0.06$ & $1.16 \pm 0.07$ & 0.430 \\
\hline Protein & $0.32 \pm 0.01$ & $0.32 \pm 0.02$ & 0.821 \\
\hline Lactose & $0.44 \pm 0.02$ & $0.42 \pm 0.02$ & 0.706 \\
\hline \multicolumn{4}{|l|}{ Milk composition $(\%)^{*}$} \\
\hline Fat & $4.23 \pm 0.16$ & $4.18 \pm 0.07$ & 0.799 \\
\hline Solids not fat & $8.22 \pm 0.10$ & $8.17 \pm 0.13$ & 0.759 \\
\hline Total solids & $12.45 \pm 0.14$ & $12.35 \pm 0.17$ & 0.668 \\
\hline Protein & $3.30 \pm 0.06$ & $3.40 \pm 0.03$ & 0.163 \\
\hline Lactose & $4.40 \pm 0.07$ & $4.50 \pm 0.02$ & 0.192 \\
\hline \multicolumn{4}{|l|}{ Feed efficiency } \\
\hline Milk (kg)/DMI (kg) & $1.13 \pm 0.06$ & $1.04 \pm 0.07$ & 0.313 \\
\hline 4\% FCM (kg)/DMI (kg) & $1.17 \pm 0.07$ & $1.07 \pm 0.07$ & 0.297 \\
\hline ECM (kg)/DMI (kg) & $1.27 \pm 0.07$ & $1.17 \pm 0.08$ & 0.327 \\
\hline
\end{tabular}

FCM - fat corrected milk; ECM: energy corrected milk. CON - Basal diet without additive; RAS - Basal diet + 2 g/animal/day of ricinoleic acid; ${ }^{\circledR}$ Milk samples were collected at fortnightly intervals for analysis of milk composition

Table 3. The effect of supplementation of ricinoleic acid on the milk fatty acids profile $(\mathrm{g} / 100 \mathrm{~g})$ in lactating Kankrej cows $(\mathrm{n}=20)$

\begin{tabular}{|l|c|c|c|}
\hline Fatty acids & CON & RAS & P value \\
\hline C4:0 & $2.24^{\mathrm{a}} \pm 0.18$ & $2.79^{\mathrm{b}} \pm 0.07$ & 0.012 \\
\hline C6:0 & $1.46^{\mathrm{a}} \pm 0.10$ & $1.99^{\mathrm{b}} \pm 0.13$ & 0.004 \\
\hline C8:0 & $1.08^{\mathrm{a}} \pm 0.05$ & $1.73^{\mathrm{b}} \pm 0.15$ & 0.001 \\
\hline C10:0 & $2.23 \pm 0.16$ & $2.39 \pm 0.14$ & 0.464 \\
\hline C12:0 & $2.58 \pm 0.18$ & $2.96 \pm 0.20$ & 0.181 \\
\hline C14:0 & $13.55 \pm 0.51$ & $13.10 \pm 0.43$ & 0.506 \\
\hline C14:1 & $0.87 \pm 0.05$ & $0.90 \pm 0.08$ & 0.810 \\
\hline C15:0 & $0.51 \pm 0.05$ & $0.63 \pm 0.06$ & 0.138 \\
\hline C15:1 & $0.16 \pm 0.02$ & $0.13 \pm 0.01$ & 0.150 \\
\hline C16:0 & $32.19^{\mathrm{b}} \pm 0.95$ & $26.06^{\mathrm{a}} \pm 1.05$ & 0.001 \\
\hline C16:1 & $2.47 \pm 0.10$ & $2.52 \pm 0.11$ & 0.732 \\
\hline
\end{tabular}


M. M. Pawar et al.: Production performance of dairy cows fed with ricinoleic acid

Table 3. The effect of supplementation of ricinoleic acid on the milk fatty acids profile $(\mathrm{g} / 100 \mathrm{~g})$ in lactating Kankrej cows $(\mathrm{n}=20)$ (continued)

\begin{tabular}{|l|c|c|c|}
\hline Fatty acids & CON & RAS & P value \\
\hline C17:0 & $0.64 \pm 0.04$ & $0.71 \pm 0.04$ & 0.178 \\
\hline C17:1 & $0.20 \pm 0.01$ & $0.18 \pm 0.01$ & 0.220 \\
\hline C18:0 & $16.03 \pm 0.79$ & $16.84 \pm 0.56$ & 0.412 \\
\hline C18:1 & $19.44 \pm 0.89$ & $20.81 \pm 1.43$ & 0.427 \\
\hline C18:2 & $1.67^{\mathrm{a}} \pm 0.10$ & $2.90^{\mathrm{b}} \pm 0.36$ & 0.004 \\
\hline C18:3 & $0.91^{\mathrm{a}} \pm 0.05$ & $1.75^{\mathrm{b}} \pm 0.20$ & 0.001 \\
\hline C20:0 & $0.19 \pm 0.02$ & $0.22 \pm 0.02$ & 0.335 \\
\hline C22:0 & $1.58 \pm 0.12$ & $1.39 \pm 0.11$ & 0.255 \\
\hline SFA & $74.27 \pm 0.92$ & $70.82 \pm 1.40$ & 0.055 \\
\hline UFA & $25.73 \pm 0.92$ & $29.18 \pm 1.40$ & 0.055 \\
\hline MUFA & $23.15 \pm 0.88$ & $24.53 \pm 1.46$ & 0.430 \\
\hline PUFA & $2.58^{\mathrm{a}} \pm 0.10$ & $4.65^{\mathrm{b}} \pm 0.48$ & 0.001 \\
\hline U/S & $0.35 \pm 0.02$ & $0.42 \pm 0.03$ & 0.057 \\
\hline
\end{tabular}

${ }^{a, b}$ values in a row with different superscripts differed significantly $(\mathrm{P}<0.05)$; CON - Basal diet without additive; RAS - Basal diet + $2 \mathrm{~g} /$ animal/day of ricinoleic acid; SFA - saturated fatty acids; UFA - unsaturated fatty acids; MUFA - monounsaturated fatty acids; PUFA - polyunsaturated fatty acids; $\mathrm{U} / \mathrm{S}=$ sum of unsaturated fatty acids/sum of saturated fatty acids.

Table 4. The effect of supplementation of ricinoleic acid on the haematological parameters of lactating Kankrej cows $(\mathrm{n}=20)$

\begin{tabular}{|l|c|c|c|}
\hline Parameters & CON & RAS & P value \\
\hline Haemoglobin $(\mathrm{g} / \mathrm{dL})$ & $10.53 \pm 0.23$ & $10.36 \pm 0.23$ & 0.613 \\
\hline Haematocrit $(\mathrm{L} / \mathrm{L})$ & $32.34 \pm 1.08$ & $31.15 \pm 0.70$ & 0.365 \\
\hline Erythrocytes $\left(10^{6} / \mu \mathrm{L}\right)$ & $6.97 \pm 0.17$ & $6.74 \pm 0.17$ & 0.349 \\
\hline MCV $(\mathrm{fL})$ & $45.88 \pm 0.32$ & $44.89 \pm 0.52$ & 0.121 \\
\hline $\mathrm{MCH}(\mathrm{pg})$ & $15.76 \pm 0.32$ & $15.24 \pm 0.29$ & 0.246 \\
\hline MCHC $(\mathrm{g} / \mathrm{dL})$ & $34.08 \pm 0.37$ & $33.71 \pm 0.26$ & 0.425 \\
\hline Leukocytes $\left(10^{3} / \mu \mathrm{L}\right)$ & $8.19 \pm 0.60$ & $7.50 \pm 0.37$ & 0.338 \\
\hline Neutrophils $\left(10^{3} / \mu \mathrm{L}\right)$ & $3.31 \pm 0.23$ & $3.50 \pm 0.26$ & 0.593 \\
\hline Lymphocytes $\left(10^{3} / \mu \mathrm{L}\right)$ & $3.53 \pm 0.26$ & $3.44 \pm 0.27$ & 0.812 \\
\hline Monocytes $\left(10^{3} / \mu \mathrm{L}\right)$ & $0.70 \pm 0.05$ & $0.63 \pm 0.04$ & 0.308 \\
\hline
\end{tabular}

$\mathrm{MCV}$ - mean corpuscular volume, MCH - mean corpuscular haemoglobin, MCHC - mean corpuscular haemoglobin concentration; $\mathrm{CON}$ - Basal diet without additive; RAS - Basal diet $+2 \mathrm{~g} /$ animal/day of ricinoleic acid 
M. M. Pawar et al.: Production performance of dairy cows fed with ricinoleic acid

Table 5. The effect of supplementation of ricinoleic acid on blood biochemical profile of lactating Kankrej cows $(\mathrm{n}=20)$

\begin{tabular}{|l|c|c|c|}
\hline Parameters & CON & RAS & P value \\
\hline Glucose (mg/dL) & $62.10 \pm 1.50$ & $59.00 \pm 1.81$ & 0.204 \\
\hline Total protein (g/dL) & $7.66 \pm 0.11$ & $7.71 \pm 0.15$ & 0.792 \\
\hline Albumin (g/dL) & $2.90 \pm 0.06$ & $2.89 \pm 0.07$ & 0.912 \\
\hline Globulin (g/dL) & $4.76 \pm 0.12$ & $4.82 \pm 0.15$ & 0.403 \\
\hline Urea (mg/dL) & $39.28 \pm 1.69$ & $41.48 \pm 1.93$ & 0.295 \\
\hline Creatinine (mg/dL) & $1.40 \pm 0.11$ & $1.27 \pm 0.07$ & 0.421 \\
\hline Triglycerides (mg/dL) & $34.96 \pm 2.69$ & $32.46 \pm 1.40$ & 0.232 \\
\hline Cholesterol (mg/dL) & $218.9 \pm 16.14$ & $190.5 \pm 16.39$ & 0.159 \\
\hline ALT (U/L) & $41.81 \pm 3.84$ & $49.34 \pm 3.39$ & 0.836 \\
\hline AST (U/L) & $68.98 \pm 4.32$ & $67.46 \pm 5.83$ & 0.168 \\
\hline ALP (U/L) & $227.7 \pm 22.33$ & $189.8 \pm 14.06$ & 0.852 \\
\hline GGT (U/L) & $10.63 \pm 2.52$ & $10.11 \pm 1.09$ & 0.424 \\
\hline Calcium (mg/dL) & $7.70 \pm 0.22$ & $7.91 \pm 0.12$ & 0.234 \\
\hline Phosphorus (mg/dL) & $6.83 \pm 0.22$ & $7.32 \pm 0.33$ & \\
\hline
\end{tabular}

ALT: alanine aminotransferase; AST: aspartate aminotransferase; ALP: alkaline phosphatase; GGT: gamma-glutamyl transferase. CON: Basal diet without additive; RAS: Basal diet +2 g/animal/day of ricinoleic acid

\section{Discussion}

In the current study, cows in the RAS group were fed $2 \mathrm{~g}$ ricinoleic acid from castor oil daily which as a functional oil provides health benefits such as antimicrobial (FERREIRA et al. 2002), antiinflammatory (VIEIRA et al. 2000), anti-oxidative (TREVISAN et al. 2006), and gastro-protective (HAMAD and MUBOFU, 2015) properties, and can be used as a phytogenic feed additive as an alternative to antibiotics. There was no adverse effect of ricinoleic acid supplementation on feed intake. Similarly, FERREIRA DE JESUS et al. (2016) found that supplementation of $500 \mathrm{mg} / \mathrm{kg}$ DM functional oil (a blend of cashew nut shell oil [CSNL] and castor oil [CO]) had a non-significant $(\mathrm{P}>0.05)$ effect on dry matter intake $(\mathrm{kg} / \mathrm{d}$ and $\%$ live weight) in lactating Holstein cows. Additionally, other studies that evaluated CSNL (functional oil) in the diet of dairy cows also described no differences in DM intake (COUTINHO et al., 2014; BRANCO et al., 2015). No impact of functional oils on feed efficiency in dairy cows was reported by FERREIRA DE JESUS et al. (2016) and GHIZZI et al. (2018).
In the present study, there was no effect on milk yield (milk, FCM and ECM) due to dietary ricinoleic acid. Similarly, previous studies (COUTINHO et al. 2014; BRANCO et al. 2015; GHIZZI et al. 2018) reported that feeding functional oil (blend of CSNL and $\mathrm{CO}$ ) had no impact on milk or FCM yield in dairy cows. However, GANDRA et al. (2014) observed significantly $(\mathrm{P}<0.05)$ higher milk $(24.16$ vs. $22.47 \mathrm{~kg} / \mathrm{d}$ ) and FCM yields (26.08 vs. 23.44 $\mathrm{kg} / \mathrm{d}$ ) in Simmental dairy cows fed with ricinoleic acid $(2 \mathrm{~g} / \mathrm{d})$ from castor oil. FERREIRA DE JESUS et al. (2016) reported that feeding $500 \mathrm{mg} / \mathrm{kg}$ DM functional oil to Holstein cows significantly increased $(\mathrm{P}<0.05)$ milk yield $(25.1$ vs. $24.6 \mathrm{~kg} / \mathrm{d})$. The discrepancies between studies on the effect of functional oil on the milk yield of dairy cows might be due to feeding with individual or combinations of oils, types of diet, added levels of oil and the different durations of the experiments. No changes in milk composition were observed in the current study. These findings were in agreement with other studies (COUTINHO et al., 2014; GANDRA et al., 2014; BRANCO et al. 2015; FERREIRA DE JESUS et al., 2016). Nonetheless, PARENTE et al. 
(2018) found that feeding $30 \mathrm{~g} / \mathrm{kg}$ DM of castor oil to ewes significantly $(\mathrm{P}<0.05)$ increased milk fat and total solid percentages as compared to the control, whereas milk protein and lactose percentages were unchanged.

In the current study, dietary addition of ricinoleic acid altered the milk fatty acid (FA) profile. The milk FA profile depends on the type of animal, the ration composition, type and dose of oil fed, along with the interrelationship between dietary lipid, rumen fermentation, and metabolic changes occurring in the liver, blood, and finally in the mammary gland (KLIEM and SHINGFIELD, 2016; VARGAS-BELLO-PÉREZ et al. 2019; FERLAY and CHILLIARD, 2020). Information on the effects of feeding ricinoleic acid/castor oil/functional oil on the milk FA profiles of dairy cows is scarce. BRANCO et al. (2015) observed that feeding CNSL (functional oil) resulted in a reduction in the concentrations of $\mathrm{C} 4: 0(\mathrm{P}=0.02), \mathrm{C} 14: 0(\mathrm{P}=0.11)$ and $\mathrm{C} 18: 0(\mathrm{P}=0.06)$ compared with the control. COUTINHO et al. (2014), reported milk FA data for lactating cows receiving CSNL functional oil showed a linear decrease in $\mathrm{C} 6: 0$ and a linear increase in $\mathrm{C} 16: 1 \mathrm{n}-7$ concentrations. Recent studies have highlighted that supplementation of lipids and plant bioactive compounds leads to changes in milk fatty acids profile due to changes in the microbial population involved in the biohydrogenation process (TORAL et al., 2018; FATAHNIA et al., 2018). The lower C16:0 concentration of milk fat in RAS cows could be related to the higher C18:2 and C18:3 concentrations in the milk fat. In the mammary glands and other tissues vaccenic acid can be converted to C18:2 by the action of $\Delta 9$-desaturase (SHINGFEILD et al., 2013). This suggests that, formation of PUFA acids resulted from the ricinoleic acid which protected them from rumen biohydrogenation, or rapidly passed from the rumen to the duodenum (DOREAU et al., 2009). Long chain fatty acids (C14:0, C16:0 and C18:0) are abundantly present in ruminant milk fat and they are preferentially stored as body fat in humans. They are considered as hyper-cholesterolemic, would have an impact on cardiovascular health parameters (GÓMEZ-CORTÉS et al. 2018).
Elevated concentrations of UFA and PUFA in milk fat have numerous health benefits for humans (SHAHIDI and AMBIGAIPALAN, 2018). Therefore, nutritional interventions that increase the percentages of UFA and PUFA content in the milk fat of dairy cows are of interest. Feeding dairy cows ricinoleic acid in their diet might be one such way.

The results obtained in this study indicate that ricinoleic acid supplementation did not have any adverse effect on the health and welfare of the animals. In accordance with the present findings, GANDRA et al. (2014) reported a non-significant effect on red blood cell and white blood cell counts after supplementation with ricinoleic acid $(2 \mathrm{~g} / \mathrm{d})$ from castor oil, in Simmental dairy cows. Feeding of functional oil did not impact $(\mathrm{P}>0.05)$ haematological indices in feedlot cattle (GANDRA et al., 2012; CRUZ et al., 2014; VALERO et al., 2016). Similar to the present findings, no differences were observed in the blood metabolites of dairy cows fed functional oils in other studies (BRANCO et al., 2015; GHIZZI et al., 2018). On the contrary, a decrease in the concentrations of serum urea in cows fed functional oil was reported by GANDRA et al. (2014) and FERREIRA DE JESUS et al. (2016).

\section{Conclusions}

On the basis of the results of the present study, it was concluded that supplementation of $2 \mathrm{~g} / \mathrm{animal} /$ day ricinoleic acid from castor oil had no effect on milk yield, milk composition and haematobiochemical profile. However, it increased the milk fat percentages of unsaturated fatty acids and polyunsaturated fatty acids, and decreased milk saturated fatty acids, without any adverse effect on the health status of the cows.

\section{Acknowledgements}

The authors are thankful to the Director of Research, Sardarkrushinagar Dantiwada Agricultural University, Sardarkrushinagar, Gujarat, India, for providing the financial assistance and necessary facilities to carry out this research work. 
M. M. Pawar et al.: Production performance of dairy cows fed with ricinoleic acid

\section{References}

ALVES, S. P., C. M. ARAUJO, R. C.QUEIROGA, M. S.MADRUGA, M. O. PARENTE, A. N. MEDEIROS, R. J. BESSA (2017): New insights on the metabolism of ricinoleic acid in ruminants. J. Dairy Sci. 100, 8018-8032. DOI: $10.3168 /$ jds.2017-13117

AOAC (2007): Official Methods of Analysis. $18^{\text {th }}$ ed., Association of Official Analytical Chemists, Gaithersburg.

ASCHENBACH, J. R., N. B. KRISTENSEN, S. S. DONKIN, H. M. HAMMON, G. B. PENNER (2010): Gluconeogenesis in dairy cows: The secret of making sweet milk from sour dough. IUBMB life. 62, 869-877.

DOI: $10.1002 /$ iub. 400

BRANCO, A. F., F. GIALLONGO, T. FREDERICK, H. WEEKS, J. OH, A. N. HRISTOV (2015): Effect of technical cashew nut shell liquid on rumen methane emission and lactation performance of dairy cows. J. Dairy Sci. 98, 4030-4040.

DOI: $10.3168 /$ jds.2014-9015

COUTINHO, D. A., A. F. BRANCO, G. T. SANTOS, M. P. OSMARI, A. L. TEODORO, T. G. DIAZ (2014): Intake, digestibility of nutrients, milk production and composition in dairy cows fed on diets containing cashew nut shell liquid. Acta Sci. 36, 311-316.

DOI: $10.4025 /$ actascianimsci.v36i3.23512

CRUZ, O. T. B., M. V. VALERO, F. ZAWADZKI, D. C. RIVAROLI, R. M. DO PRADO, B. S. LIMA,I. N. DO PRADO (2014): Effect of glycerine and essential oils (Anacardium occidentale and Ricinus communis) on animal performance, feed efficiency and carcass characteristics of crossbred bulls finished in a feedlot system. Ital. J. Anim. Sci. 13, 3492.

DOI: $10.4081 /$ ijas.2014.3492

DAVIDSON, S., B. A. HOPKINS, J. ODLE, C. BROWNIE, V. FELLNER, L. W. WHITLOW (2008): Supplementing limited methionine diets with rumen-protected methionine, betaine, and choline in early lactation Holstein cows. J. Dairy Sci. 91, 1552-1559.

DOI: $10.3168 /$ jds.2007-0721

DOREAU, M., S. LAVERROUX, J. NORMAND, G. CHESNEAU, F. GLASSER (2009): Effect of linseed fed as rolled seeds, extruded seeds or oil on fatty acid rumen metabolism and intestinal digestibility in cows. Lipids 44 , 53-62.

DOI: $10.1007 / \mathrm{s} 11745-008-3250-\mathrm{x}$

FATAHNIA, F., A. AZARFAR, S. MENATIAN, S. J. GHASEMI, A. POORMALEKSHAHI, A. N. SHOKRI (2018). Effect of diets containing roasted soybean, extruded soybean or their combination on performance and milk fatty acid profile of lactating Holstein cows. Iran. J. Vet. Res. 19, 276-282.

FERLAY, A., Y. CHILLIARD (2020): Effect of linseed, sunflower, or fish oil added to hay-, or corn silage-based diets on milk fat yield and trans-C18: 1 and conjugated linoleic fatty acid content in bovine milk fat. Livest. Sci. 235,104005 .

DOI: 10.1016/j.livsci.2020.104005

FERREIRA, C. M., O. P. D. S. ROSA, S. A. TORRES, F. B. D. A.FERREIRA, N. BERNARDINELLI (2002): Activity of endodontic antibacterial agents against selected anaerobic bacteria. Braz. Dent. J. 13, 118-122.

DOI: $10.1590 / \mathrm{S} 0103-64402002000200008$

FERREIRA DE JESUS, E., T. A. DEL VALLE, G. D. CALOMENI, T. H. SILVA, C. S. TAKIYA, T. H. A. VENDRAMINI, P. G. PAIVA, G. G. SILVA, A. S. NETTO, F. P. RENNÓ (2016): Influence of a blend of functional oils or monensin on nutrient intake and digestibility, ruminal fermentation and milk production of dairy cows. Anim. Feed Sci. Technol. 219, 59-67.

DOI: 10.1016/j.anifeedsci.2016.06.003

GAINS, W.L. (1928): The energy basis of measuring milk yield in dairy cows. University of Lllinois. Agriculture Experiment Station. Bulletin No. 308.

GANDRA, J. R., P. C. NUNES GIL, N. R. B. CONSOLO, E. R. S. GANDRA, A. A. O. GOBESSO (2012): Addition of increasing doses of ricinoleic acid from castor oil (Ricinus communis L.) in diets of Nellore steers in feedlots. J. Anim. Feed Sci. 21, 566-576.

DOI: $10.22358 /$ jafs/66131/2012

GANDRA, J. R., P. C. NUNES GIL, E. R. S. GANDRA, T. A. VALE, R. V. BARLETTA, F. ZANFERARI, E. FERREIRA DE JESUS, C. S. TAKIYA, R. D. MINGOTI, G. F. AlMEIDA, P. G. PAIVA, A. A. O. GOBESSO (2014): Productive performance of Simmental dairy cows supplemented with ricinoleic acid from castor oil. Arch. Zootec. 63, 575-585.

DOI: $10.4321 / \mathrm{s} 0004-05922014000400002$

GHIZZI, L. G., T. A. DEL VALLE, C. S. TAKIYA, G. G. DA SILVA, E. M. ZILIO, N. T. GRIGOLETTO, L. S. MARTELLO, F. P. RENNO (2018): Effects of functional oils on ruminal fermentation, rectal temperature, and performance of dairy cows under high temperature humidity index environment. Anim. Feed Sci. Technol. 246, 158-166.

DOI: 10.1016/j.anifeedsci.2018.10.009

GÓMEZ-CORTÉS, P., M. JUÁREZ, M. A. DE LA FUENTE (2018): Milk fatty acids and potential health benefits: An updated vision. Trends Food Sci. Tech. 81, 1-9.

DOI: $10.1016 /$ j.tifs.2018.08.014

HAMAD, F. B., E. B. MUBOFU (2015): Potential biological applications of bio-based anacardic acids and their derivatives. Int. J. Mol. Sci. 16, 8569-8590.

DOI: $10.3390 /$ ijms 16048569

HAMMON, H. M., C. C. METGES, A. SCHULZ, P. JUNGHANS, J. STEINHOFF, F. SCHNEIDER, R. 
PFUHL, R. M. BRUCKMAIER, R. WEIKARD, C. KÜHN (2010): Differences in milk production, glucose metabolism, and carcass composition of 2 Charolais $\times$ Holstein F2 families derived from reciprocal paternal and maternal grandsire crosses. J. Dairy Sci. 93, 3007-3018.

DOI: $10.3168 /$ jds.2009-2931

HAUSMANN, J., C. DEINER, A. K. PATRA, I. IMMIG, A. STARKE, J. R. ASCHENBACH (2018): Effects of a combination of plant bioactive lipid compounds and biotin compared with monensin on body condition, energy metabolism and milk performance in transition dairy cows. PloS one. 13, e0193685.

DOI: 10.1371/journal.pone.0193685

ICAR (2013): Nutrient Requirements of Cattle and Buffalo. Indian Council of Agricultural Research, New Delhi, India.

JOSHI, P. C. (2019): Productive performance of lactating Kankrej cows supplemented with castor (Ricinus communis) oil. MVSc Thesis, Sardarkrushinagar Dantiwada Agricultural University, Gujarat, India.

KANG, S., R. SUZUKI, Y. SUZUKI, S. KOIKE, K. NAGASHIMA, Y. KOBAYASHI (2018): Rumen responses to dietary supplementation with cashew nut shell liquid and its cessation in sheep. Anim. Sci. J. 89, 1549-1555.

DOI: $10.1111 /$ asj.13100

KLIEM, K. E., K. J. SHINGFIELD (2016): Manipulation of milk fatty acid composition in lactating cows: Opportunities and challenges. Eur. J. Lipid Sci. Technol. 118, 1661-1683. DOI: 10.1002/ejlt.201400543

KONDA, S., R. ONODERA, E. KANCHANASATIT, P. BOONSAEN, S. SAWANON, K. NAGASHIMA, Y. SUZUKI, S. KOIKE, Y. KOBAYASHI (2019): Effect of cashew nut shell liquid feeding on fermentation and microbiota in the rumen of Thai native cattle and swamp buffaloes. Livest. Sci. 226, 99-106.

DOI: 10.1016/j.livsci.2019.06.011

MATLOUP, O. H., A. A. EL TAWAB, A. A. HASSAN, F. I. HADHOUD, M. S. A. KHATTAB, M. S. KHALEL, S. M. A. SALLAM, A. E. KHOLIF (2017): Performance of lactating Friesian cows fed a diet supplemented with coriander oil: feed intake, nutrient digestibility, ruminal fermentation, blood chemistry, and milk production. Anim. Feed Sci. Technol. 226, 88-97.

DOI: 10.1016/j.anifeedsci.2017.02.012

MORALES, E. R., M. A. MATA ESPINOSA, N. MCKAIN, R. J. WALLACE (2012): Ricinoleic acid inhibits methanogenesis and fatty acid biohydrogenation in ruminal digesta from sheep and in bacterial cultures. J. Anim. Sci. 90, 4943-4950.

DOI: $10.2527 /$ jas.2011-4670

NRC (2001): Nutrient Requirements of Dairy Cattle. $7^{\text {th }}$ rev. ed., National Academy of Sciences, Washington, D.C.

DOI: $10.17226 / 9825$
O'FALLON, J. V., J. R. BUSBOOM, M. L. NELSON, C. T. GASKINS (2007): A direct method for fatty acid methyl ester (FAME) synthesis: Application to wet meat tissues, oils and feedstuffs. J. Anim. Sci. 85, 1511-1521.

DOI: $10.2527 /$ jas.2006-491

PARENTE, M. D. O. M., I. SUSIN, C. P. NOLli, E. M. FERREIRA, R. S. GENTIL, D. M. POLIZEL, A. V. PIRES, S. P. ALVES,R. J. B. BESSA (2018): Effects of supplementation with vegetable oils, including castor oil, on milk production of ewes and on growth of their lambs. J. Anim. Sci. 96, 354-363.

DOI: $10.1093 /$ jas/skx015

PAWAR, M. M., D. N. KAMRA, L. C. CHAUDHARY, N. AGARWAL, V. B. CHATURVEDI (2019): Nutrients utilization, methane emission, immune function, blood metabolites and performance of buffalo calves fed Trachyspermum copticum seed oil. Indian J. Anim. Sci. 89, 63-67.

SERADJ, A. R., J. TORRENT, G. DE LA FUENTE, J. BALCELLS (2017): In vitro effects of a commercial blend of functional oils on fermentation, methane production and responsible methanogenic archaea. XVII Jornadas sobre Producción Animal. Zaragoza, España. pp, 252-254.

SHAHIDI, F., P. AMBIGAIPALAN (2018): Omega-3 polyunsaturated fatty acids and their health benefits. Annu. Rev. Food Sci. Technol. 9, 345-381.

SNEDECOR, G. W., W. G. COCHRAN (1994): Statistical methods. $8^{\text {th }}$ ed. Ames: Iowa State University Press, USA.

TORAL, P. G., F. J. MONAHAN, G. HERVÁS, P. FRUTOS, A. P. MOLONEY (2018): Modulating ruminal lipid metabolism to improve the fatty acid composition of meat and milk: Challenges and opportunities. Animal. 12, s272-s281.

DOI: $10.1017 / \mathrm{S} 1751731118001994$

TORRENTES-ESPINOZA, G., B. C. MIRANDA, J. VEGABAUDRIT, J. F. MATA-SEGREDA (2017): Castor oil (Ricinus communis) supercritical methanolysis. Energy. 140, 426-435.

DOI: 10.1016/j.energy.2017.08.122

TREVISAN, M.T.S., B. PFUNDSTEIN, R. HAUBNER, WÜRTELE, B. SPIEGELHALDER, H. BARTSCH, R. W. OWEN (2006): Characterization of alkyl phenols in cashew (Anacardium occidentale) products and assay of their antioxidant capacity. Food Chem. Toxicol. 44, 188197.

DOI: $10.1016 /$ j.fct.2005.06.012

VALERO, M. V., M. S. FARIAS, F. ZAWADZKI, R. M. D. PRADO, C. A. FUGITA, D. C. RIVAROLI, M. G. ORNAGHI,I. N. D. PRADO (2016): Feeding propolis or essential oils (cashew and castor) to bulls: performance, digestibility, and blood cell counts. Rev. Colomb. Cienc. Pec. 29, 33-42.

DOI: 10.17533/udea.rccp.v29n1a04 
VAN SOEST, P. J., J. B. ROBERTSON, B. A. LEWIS (1991): Methods for dietary fiber, neutral detergent fiber, and nonstarch polysaccharides in relation to animal nutrition. Rev. Med. Vet. 74, 3593-3597.

DOI: $10.3168 /$ jds.s0022-0302(91)78551-2

VARGAS-BELLO-PÉREZ, E., N. CANCINO-PADILLA, C. GELDSETZER-MENDOZA, S. VYHMEISTER, M. S. MORALES, H. LESKINEN, J. ROMERO, P. C. GARNSWORTHY, R. A. IBÁÑEZ (2019): Effect of feeding cows with unsaturated fatty acid sources on milk production, milk composition, milk fatty acid profile, and physicochemical and sensory characteristics of ice cream. Animals. 9, 568.

DOI: $10.3390 /$ ani9080568

VIEIRA, C., S. EVANGELISTA, R. CIRILLO, A. LIPPI, C. A. MAGGI, S. MANZINI (2000): Effect of ricinoleic acid in acute and sub-chronic experimental models of inflammation. Mediators Inflamm. 9, 223-228.

DOI: $10.1080 / 09629350020025737$

PAWAR, M. M., P. C. JOShI, Y. M. GAMI, S. S. PATIL, M. P. PATEL, J. G. PATEL: Učinak ricinoleične kiseline iz ricinusova ulja na proizvodna svojstva i hemato-biokemijski profil krava pasmine Kankrej u laktaciji. Vet. arhiv 91, 125-135, 2021.

\section{SAŽETAK}

Cilj istraživanja bio je procijeniti učinak ricinoleične kiseline iz ricinusova ulja na prinos mlijeka, kemijski sastav mlijeka, profil masnih kiselina u mlijeku te na hemato-biokemijski profil krava pasmine Kankrej u laktaciji. Ukupno 20 krava u laktaciji podijeljeno je u: kontrolnu skupinu (CON), skupinu koja je dobivala osnovnu hranu, bez dodataka i pokusnu skupinu (RAS), koja je dobivala osnovnu hranu i 2 g po životinji dnevno ricinoleične kiseline iz ricinusova ulja. Ricinoleična kiselina nije imala učinka $(\mathrm{P}>0,05)$ na unos suhe tvari i iskorištavanje hrane. Dodatak ricinoleične kiseline nije utjecao $(\mathrm{P}>0,05)$ na prinos mlijeka (mlijeko, obogaćeno mlijeko s $4 \%$ masnoće i energijski obogaćeno mlijeko). Sastav mlijeka nije pokazao znakovite razlike među skupinama. Uočen je znakovito veći postotak C4:0, C6:0 i C8:0 u mlijeku u skupini RAS $(P<0,05)$ nego u skupini CON. Niži postotak $\mathrm{C} 16: 0$ u mlijeku $(\mathrm{P}<0,05)$ uočen je u skupini RAS u usporedbi sa skupinom CON. Povećan postotak C18:2 i C18:3 pronađen je u skupini RAS. Zapaženo je smanjenje udjela zasićenih masnih kiselina u mlijeku $(P=0,055)$, dok je postotak nezasićenih masnih kiselina $u$ mlijeku u skupini RAS povećan u odnosu na skupinu CON. Udio višestruko nezasićenih masnih kiselina $(\mathrm{P}<0,05)$ povećan je u skupini RAS. Nije bilo znakovite razlike $(\mathrm{P}>0,05) \mathrm{u}$ hemato-biokemijskom profilu skupina CON i RAS. Zaključeno je da dodatak $2 \mathrm{~g}$ ricinoleične kiseline po životinji dnevno ne utječe na prinos i sastav mlijeka te hematobiokemijski profil, međutim povećava postotak mliječne masti, nezasićenih masnih kiselina i višestruko nezasićenih masnih kiselina, a smanjuje postotak zasićenih masnih kiselina bez posljedica za zdravlje krava.

Ključne riječi: krava pasmine Kankrej; prinos mlijeka; masnokiselinski status; krvni metaboliti; ricinoleična kiselina 
